Article

\title{
Improving the Mechanical and Electrical Properties of Ceramizable Silicone Rubber/Halloysite Composites and Their Ceramic Residues by Incorporation of Different Borates
}

\author{
Jianhua Guo ${ }^{1,2, *}$, Xuming Chen ${ }^{1}$ and Yong Zhang ${ }^{1}$ \\ 1 School of Materials Science and Engineering, South China University of Technology, Guangzhou 510640, \\ China; chenxm233@126.com (X.C.); tropo@foxmail.com (Y.Z.) \\ 2 Institute of Modern Industrial Technology of SCUT in Zhongshan, Zhongshan 528400, China \\ * Correspondence: psjhguo@scut.edu.cn
}

Received: 9 March 2018; Accepted: 27 March 2018; Published: 1 April 2018

\begin{abstract}
Ceramizable silicone rubber (MVQ)/halloysite (HNT) composites were fabricated by incorporation of three different borates, including sodium tetraborate decahydrate, ammonium pentaborate, and zinc borate into MVQ matrix, respectively. The composites without any borates were also prepared as control. The effect of the borates on the mechanical and electrical properties of MVQ/HNT composites was investigated. The ceramic residues were obtained from the decomposition of the composites after sintering at $1000^{\circ} \mathrm{C}$. The effect of the borates on the linear shrinkage, weight loss, and flexural and impact strength of the residues was also studied. The fracture surfaces of the composites and their corresponding residues were observed by SEM. The proposed ceramizable mechanism of the composites by incorporation of different borates was revealed by XRD analysis.
\end{abstract}

Keywords: ceramizable silicone rubber; borate; halloysite; composite; ceramizable mechanism

\section{Introduction}

Ceramizable silicone rubber (MVQ)-based composites have good processability like common elastomers at room temperature and transform into hard ceramic residues in fire environments or at elevated temperatures, which are desired materials to fulfill the increasing requirements in special applications such as fire resistant wires and cables [1]. Commonly, ceramizable silicone rubber-based composites are composed by polysiloxane elastomer, mineral fillers (montmorillonite, kaolin, talc, mica, etc.) [2-7], fluxing agents (glass frit, ammonium polyphosphate, etc.) [8-10], and other additives. Herein, fluxing agents are important components for ceramizable MVQ-based composites, which will be melted at elevated temperatures to merge some residues derived from the pyrolysis products of the composites. Furthermore, fluxing agent can promote low temperature ceramization and improve the mechanical strength of the ceramic residues [11-13]. At present, many studies have been conducted on the properties of ceramizable MVQ-based composites with the addition of glass frits with low softening point temperature. For example, Mansouri et al. [14] found that silicone rubber by incorporation of $2.5 \mathrm{wt} \%$ glass frits with a softening point temperature of $525^{\circ} \mathrm{C}$ can increase the flexural strength of the residues from 0.42 to $2.54 \mathrm{MPa}$ after firing at $800{ }^{\circ} \mathrm{C}$. Guo et al. [15] showed that the flexural strength of ceramic residues after sintering at $1000^{\circ} \mathrm{C}$ increased from 2 to $13.3 \mathrm{MPa}$ when the loading of glass frits with a softening point temperature of $480^{\circ} \mathrm{C}$ increased from 0 to $30 \mathrm{phr}$. However, the addition of glass frits will lead to a decrease of thermal stability of silicone rubber due to the catalyzed degradation 
effect of metal oxides decomposed from the glass frits [16]. Thus, some other fluxing agents except for glass frits are urgently needed to prepare ceramizable MVQ-based composites.

It was reported that zinc borate $(\mathrm{ZB})$ can act as flame retardant, smoke suppressant, and antitracking agent in both halogen-containing and halogen-free polymers [17]. The presence of $Z B$ can also result in a significant char residue formation. Moreover, ZB plays a role of glass phase, helping to form a bridge between polymer matrix and mineral fillers, which is used extensively in polyvinyl chloride, polyamide, polyolefin, epoxy, phenolic, and poly(vinyl acetate) (PVAc) [18]. As we know that boron oxide $\left(\mathrm{B}_{2} \mathrm{O}_{3}\right)$ will be generated by the decomposition of zinc borate after heating, which provides afterglow suppression in polymers. Moreover, $\mathrm{B}_{2} \mathrm{O}_{3}$ will form glassy protective surface at $325{ }^{\circ} \mathrm{C}$, which can act as a fluxing agent [19]. For example, Anyszka et al. [20] showed that the compressive strength of ceramic residues after firing at $1000{ }^{\circ} \mathrm{C}$ increased by more than four times when the loading of $\mathrm{B}_{2} \mathrm{O}_{3}$ increased from 20 to $40 \mathrm{phr}$. Halloysite nanotubes (HNTs) is a natural silicate mineral, consisting of 1:1 aluminosilicate layers with a tubular structure. Due to their special morphology, chemical structure, and surface properties, HNTs are widely used in fine ceramics [21], supported nanoparticles [22], and polymer composites [23]. However, HNTs acting as ceramic fillers and different borates acting as fluxing agents applied in MVQ have not been investigated in detail.

In this study, MVQ/HNT composites by incorporation of sodium tetraborate decahydrate, ammonium pentaborate, and zinc borate respectively, were fabricated and the composites without any fluxing agents were also prepared as control. The effect of the borates on the mechanical and electrical properties of ceramizable MVQ/HNT composites and the flexural and impact strength of the ceramic residues were investigated. Furthermore, the morphology of the ceramic residues was characterized by digital camera and SEM, and the proposed ceramic mechanism of MVQ-based composites was revealed by XRD.

\section{Experimental}

\subsection{Materials}

Methyl vinyl silicone rubber (MVQ, model 110-2, with a molecular weight of 600,000) was purchased from Caiyan Co., Ltd., Guangdong, China. Fumed silica (CABOSIL M-5) was purchased from Cabot Co., Ltd., Boston, MA, USA. Halloysites (HNTs) have a length in the range of 0.5-3.0 microns, an exterior diameter in the range of 50-70 nanometers and an internal diameter (lumen) in the range of 15-30 nanometers. HNTs were produced by Linshounanyi Mineral Factory, Hebei, China. Sodium tetraborate decahydrate $\left(\mathrm{Na}_{2} \mathrm{~B}_{4} \mathrm{O}_{7} \cdot 10 \mathrm{H}_{2} \mathrm{O}\right)$ was purchased from Fuchen Chemical Reagent Factory, Tianjin, China. Ammonium pentaborate $\left(\mathrm{NH}_{4} \mathrm{~B}_{5} \mathrm{O}_{8} \cdot 4 \mathrm{H}_{2} \mathrm{O}\right)$ was purchased from Maclin Biochemical Sci. \& Tech. Co., Ltd., Shanghai, China. Zinc borate $\left(2 \mathrm{ZnO} \cdot 3 \mathrm{~B}_{2} \mathrm{O}_{3} \cdot 3.5 \mathrm{H}_{2} \mathrm{O}\right)$ was purchased from Guanghua Sci. \& Tech. Co., Ltd., Guangdong, China. Calcium carbonate was supplied by Enping Yanhua Industrial Co., Ltd., Guangdong, China. 2,5-dimethyl-2,5-bis (tert butyl peroxy) hexane (DBPMH, model C-15) was supplied by Caiyuan Silicone Materials Co., Ltd., Guangdong, China. The formulations of MVQ/HNT composites are summarized in Table 1. The formulation symbols are labeled as $\mathrm{NaB}, \mathrm{NHB}$ and $\mathrm{ZB}$ for the composites by incorporation of sodium tetraborate decahydrate, ammonium pentaborate, and zinc borate, respectively. 
Table 1. The formulations of ceramizable MVQ/HNT composites.

\begin{tabular}{ccccc}
\hline \multirow{2}{*}{ Ingredients (phr) } & \multicolumn{4}{c}{ Symbols } \\
\cline { 2 - 5 } & Control & NaB & NHB & ZB \\
\hline Silicone rubber & 100 & 100 & 100 & 100 \\
Fumed silica & 40 & 40 & 40 & 40 \\
Halloysite & 30 & 30 & 30 & 30 \\
Calcium carbonate & 5 & 5 & 5 & 5 \\
Sodium tetraborate decahydrate & - & 7.5 & - & - \\
Ammonium pentaborate & - & - & 7.5 & - \\
Zinc borate & - & - & - & 7.5 \\
DBPMH & 2 & 2 & 2 & 2 \\
\hline
\end{tabular}

\subsection{Preparation of Silicone Rubber Based Ceramizable Composites}

All of the compounds were prepared on a two-roll mill (model XK-160, Zhanjiang Machinery Factory, Guangdong, China) with a gear ratio of 1:1.4 at room temperature. The polysiloxane elastomer was first softened, and then the fumed silica, calcium carbonate, halloysites, and borates were added until a visually good dispersion was achieved. The curing agent DBPMH was then added and processed until a homogenous batch was obtained. The total mixing time is about $20 \mathrm{~min}$. The silicone rubber compounds were cured with flat sheets by compression molding in a hydraulic press (Model KSHR100T, Kesheng Industrial Co., Ltd., Guangdong, China) at $170{ }^{\circ} \mathrm{C}$ for 15 min under $15 \mathrm{MPa}$ pressure. The post curing of samples was carried out in an oven at $180^{\circ} \mathrm{C}$ for $2 \mathrm{~h}$. The ceramizing of flat sheet samples ( $50 \mathrm{~mm}$ long, $4 \mathrm{~mm}$ thick, and $6 \mathrm{~mm}$ wide) was performed using a muffle furnace (Shenjia KL-12B, Luoyang, China). The samples were heated from room temperature to $1000{ }^{\circ} \mathrm{C}$ at a heating rate of $10^{\circ} \mathrm{C} \cdot \mathrm{min}^{-1}$, held for $30 \mathrm{~min}$, and then cooled with the muffle furnace.

\subsection{Characterization of the Composites and Ceramic Residues}

The flexural strength of the ceramic residues was determined by a flexural method using a universal testing machine (Zwick/Roell Z010, Ulm, Germany) with a cross-head speed of $0.5 \mathrm{~mm} \cdot \mathrm{min}^{-1}$ according to ASTM D790-10. The impact strength was evaluated on an electronic Charpy impact tester (Suns, Shenzhen, China) according to ASTM D256-10e1. The weight loss of the ceramic residues was calculated according to Equation (1), where $W$ is the weight loss, and $m_{1}$ and $m_{2}$ are the mass of the samples before and after sintering, respectively.

$$
W=\left(m_{1}-m_{2}\right) / m_{1} \times 100 \%
$$

The shrinkage of the ceramic residue was measured by heating flat sheet samples to $1000{ }^{\circ} \mathrm{C}$ for $30 \mathrm{~min}$ in a muffle furnace. The linear shrinkage of the ceramic residue was calculated according to Equation (2), where $L$ is the linear shrinkage, and $l_{1}$ and $l_{2}$ are the length of the samples before and after sintering, respectively.

$$
L=\left(l_{1}-l_{2}\right) / l_{2} \times 100 \%
$$

The surfaces of the ceramizable MVQ/HNT composites and corresponding ceramic residues were observed by a digital camera (Canon 600D, Tokyo, Japan). The tensile fracture surface of the composites and the impact fracture surface of the ceramic residues were sprayed with gold and then observed by scanning electron microscopy (SEM, Zeiss EVO18, Oberkochen, Germany). Thermal gravity analysis (TGA) was performed by using TG 309F1 instrument (Netzsch, Selb, Germany). Samples (weight $8 \sim 10 \mathrm{mg}$ ) were heated at a heating rate of $10^{\circ} \mathrm{C} \cdot \mathrm{min}^{-1}$ from 30 to $900{ }^{\circ} \mathrm{C}$ under nitrogen atmosphere. $\mathrm{X}$-ray diffraction spectra of the ceramic residues were obtained using an $\mathrm{X}$-ray diffractometer (XRD, PANlytical X'pert, Almelo, The Netherlands). Each scan was conducted from a $2 \theta$ angle of $5^{\circ} \sim 75^{\circ}$ at a scan rate of $1^{\circ} \cdot \mathrm{min}^{-1}$. 


\section{Results and Discussions}

\subsection{Characterization of the Borates}

Halloysites (HNTs) act as the ceramic fillers in the MVQ composites, with the similar function as kaolin, mica, talc, etc. Some borates including sodium tetraborate decahydrate (NaB), ammonium pentaborate (NHB), and zinc borate $(\mathrm{ZB})$, serve as the fluxing agents. The SEM photographs of three borates were showed in Figure 1. It can be observed in Figure $1 \mathrm{a}$ that the NaB particles are clustered at certain area and form aggregates. The average size of the NaB particles is about $200 \mu \mathrm{m}$. It is found that the NHB particles are spherical in shape with an average diameter of $50 \mu \mathrm{m}$ (Figure 1b). However, the ZB particles have sharper edges than the NaB and NHB particles as depicted in Figure 1c. The ZB particles are irregular with a much smaller size of about $1 \sim 3 \mu \mathrm{m}$.
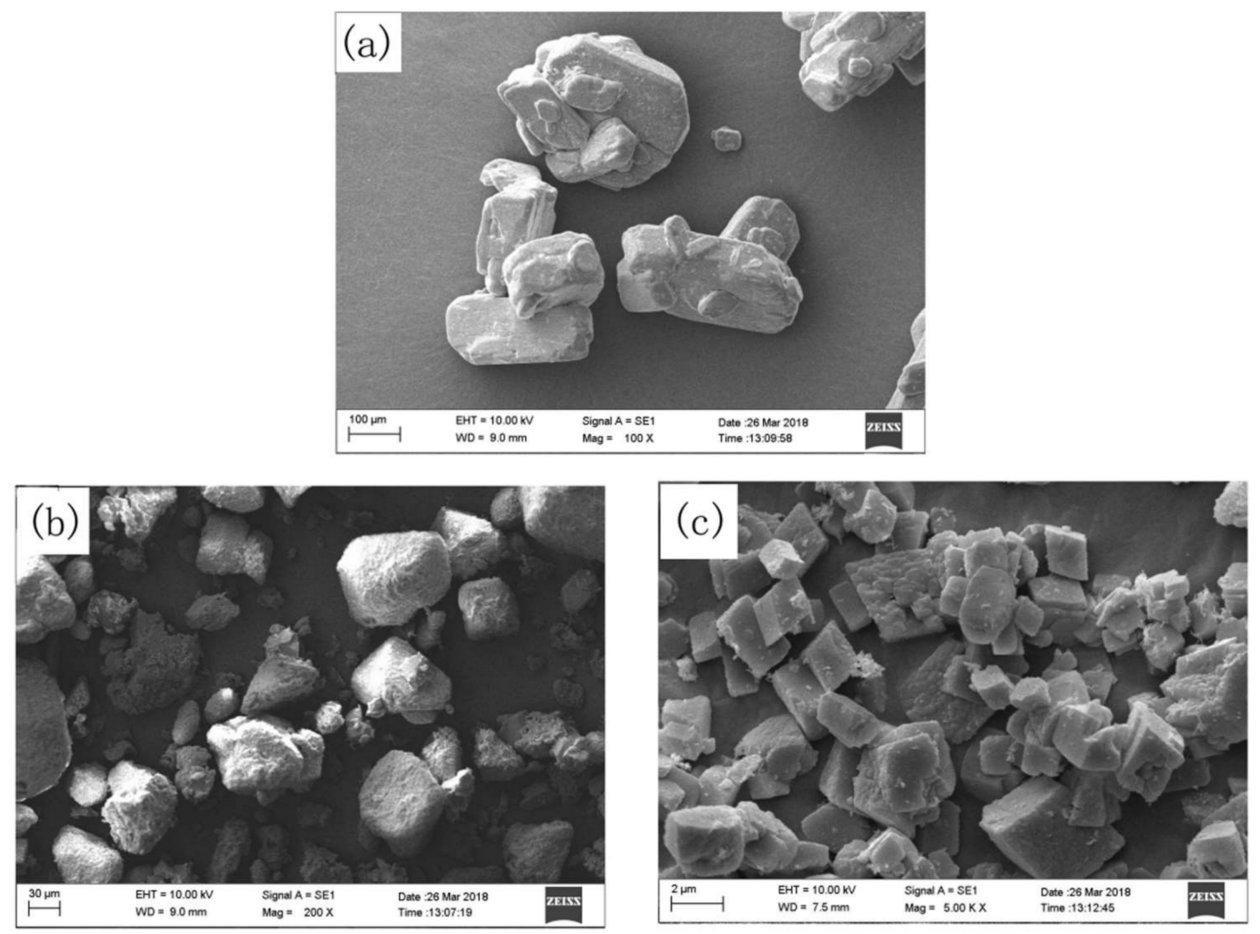

Figure 1. SEM photographs of (a) sodium tetraborate decahydrate, (b) ammonium pentaborate, and (c) zinc borate.

Thermal stability of sodium tetraborate decahydrate, ammonium pentaborate, and zinc borate was investigated in Figure 2, and the corresponding thermal parameters are listed in Table 2. It is shown that the initial decomposition temperature $\left(\mathrm{T}_{5 \%}\right)$ of sodium tetraborate decahydrate, ammonium pentaborate, and zinc borate are $66.9,144.0$, and $371.5^{\circ} \mathrm{C}$, respectively. The maximum degradation temperature $\left(\mathrm{T}_{\mathrm{d} \%}\right)$ of zinc borate is much higher than that of sodium tetraborate decahydrate and ammonium pentaborate. The mass of the residues obtained from the decomposition of sodium tetraborate decahydrate, ammonium pentaborate and zinc borate at $900{ }^{\circ} \mathrm{C}$ is $54.2,64.6$, and $84.3 \%$, respectively. Zinc borate, sodium tetraborate decahydrate, and ammonium pentaborate have one, two, and three decomposition process, respectively. The mass loss of first decomposition of sodium tetraborate decahydrate, ammonium pentaborate and zinc borate is 35.2, 20.2 and 15.5\% respectively, which is attributed to the removal of crystal water within their chemical structure. Thus, zinc borate shows better thermal stability than sodium tetraborate decahydrate and ammonium pentaborate. 


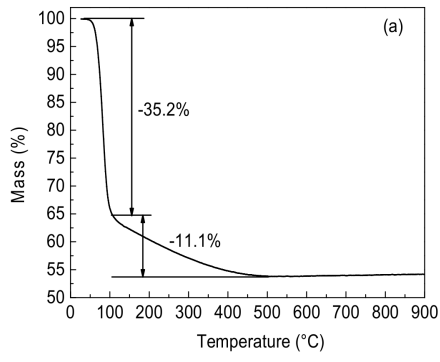

(a)

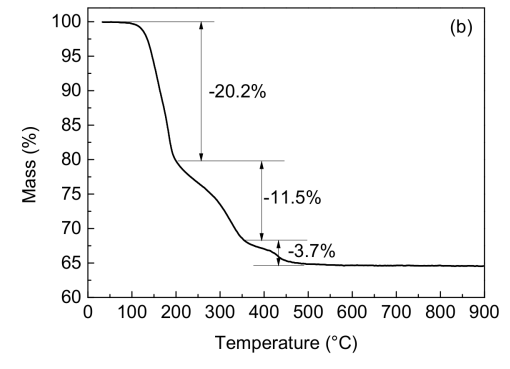

(b)

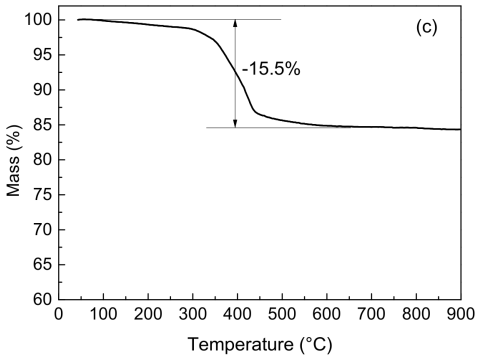

(c)

Figure 2. TGA curves of (a) sodium tetraborate decahydrate, (b) ammonium pentaborate, and (c) zinc borate.

Table 2. Thermogravimetric analysis of $\mathrm{NaB}, \mathrm{NHB}$, and ZB fillers.

\begin{tabular}{cccc}
\hline Samples & Initial Degradation Temperature, $\mathbf{T}_{\mathbf{5} \%}\left({ }^{\circ} \mathbf{C}\right)$ & Maximum Degradation Temperature, $\mathbf{T}_{\mathbf{d} \%}\left({ }^{\circ} \mathrm{C}\right)$ & Mass of Residue at $\mathbf{9 0 0}{ }^{\circ} \mathbf{C}(\%)$ \\
\hline $\mathrm{NaB}$ & 66.9 & 84.0 & 54.2 \\
$\mathrm{NHB}$ & 144.0 & 184.0 & 64.6 \\
$\mathrm{ZB}$ & 371.5 & 417.0 & 84.3 \\
\hline
\end{tabular}

Note: NaB: sodium tetraborate decahydrate; NHB: ammonium pentaborate; ZB: zinc borate.

\subsection{Effect of Borates on the Mechanical Properties of Ceramizable MVQ/HNT Composites}

The tensile stress-strain curves of ceramizable MVQ-based composites were shown in Figure 3. For the control, the tensile strength and elongation at break are $4.9 \mathrm{MPa}$ and $469 \%$, respectively. The tensile strength and elongation at break of the composites with the addition of sodium tetraborate decahydrate (abbr. as $\mathrm{NaB}$ composite) and ammonium pentaborate (abbr. as NHB composite) decrease, compared with the control. However, the tensile strength of the MVQ/HNT composite by incorporation of zinc borate (abbr. as ZB composite) is $5.5 \mathrm{MPa}$, which is $72 \%$ and $45 \%$ higher than that of the $\mathrm{NaB}$ and $\mathrm{NHB}$ composites respectively. According to the TGA results in Figure 2, the thermal decomposition of $\mathrm{NaB}$ and $\mathrm{NHB}$ fillers leads to the releasing of water steam during the curing process of the MVQ composites at $170{ }^{\circ} \mathrm{C}$ to form some voids or flaws in the MVQ matrix. The voids will result in a decrease in the mechanical properties of the MVQ composites. However, because of the higher initial decomposition temperature of $\mathrm{ZB}$, it is easier to form dense structure in the MVQ composites than another two borates. Furthermore, another reason is that $Z B$ in the composites might cause an increase in the physical crosslinking centers due to the higher electronegativity of divalent zinc ions than other elements in the blend [24], leading to an increase in the mechanical properties.

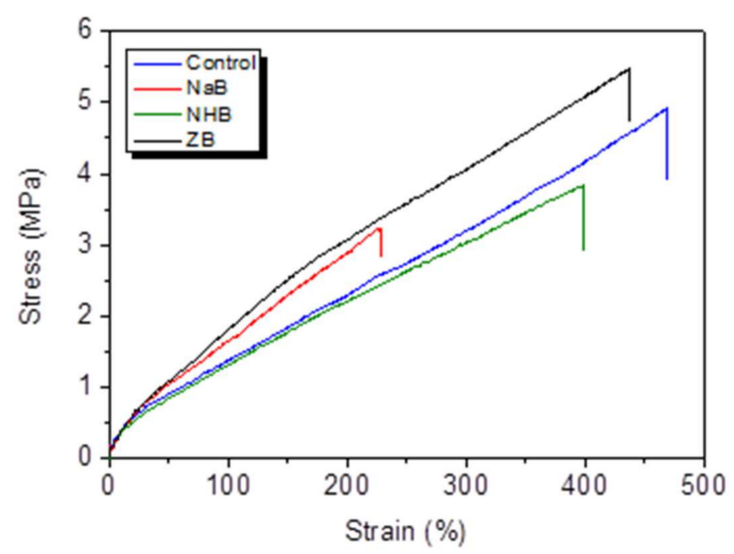

Figure 3. Tensile stress-strain curves of ceramizable MVQ/HNT composites with the addition of different borates. 


\subsection{Effect of Borates on the Electrical Properties of Ceramizable MVQ/HNT Composites}

The volume and surface resistivity of ceramizable MVQ/HNT composites with different borates were shown in Figure 4 . For the control, the volume and surface resistivity are $1.36 \times 10^{13} \Omega \cdot \mathrm{m}$ and $2.08 \times 10^{13} \Omega$, respectively. By incorporation of the borates, the electrical resistivity of the composites increase to some extent. Particularly, the ZB composite shows the maximum volume and surface resistivity with the values of $1.65 \times 10^{14} \Omega \cdot \mathrm{m}$ and $7.88 \times 10^{14} \Omega$ respectively, indicating that zinc borate will significantly improve the electrical insulation properties of MVQ. Similarly, zinc borate can improve the electrical insulation properties of ethylene-vinyl acetate copolymer (EVA)/metal hydroxide systems [17] and linear low-density polyethylene/rubbers/magnesium oxide composite [24]. These results may be attributed to collision of electrons by ZB particles inside the matrix which would obstruct the electron avalanche in the composites, and more obstruction would be generated finally resulting in higher volume and surface resistivity [24].

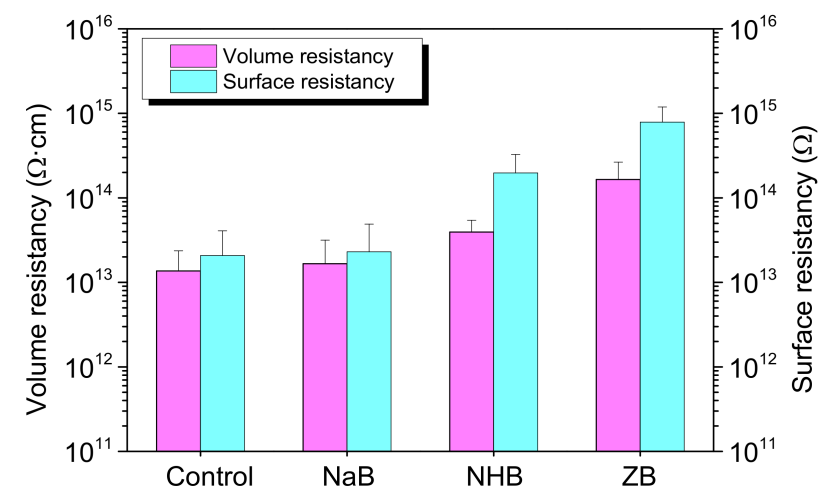

Figure 4. Electrical insulation properties of ceramizable MVQ/HNT composites with the addition of different borates.

\subsection{Effect of Borates on Linear Shrinkage and Weight Loss of Ceramic Residues}

Linear shrinkage and weight loss of the ceramic residues obtained from the decomposition of the MVQ-based composites by incorporation of different borates were shown in Figure 5 . The linear shrinkage of ceramic residues with the addition of different borates is bigger than that of the control because $\mathrm{B}_{2} \mathrm{O}_{3}$ can act as a fluxing agent, which is derived from the thermal decomposition of the borates. Then $\mathrm{SiO}_{2}$ generated from the degradation of MVQ was assembled to form a compact integration due to the adhesion of melted $\mathrm{B}_{2} \mathrm{O}_{3}$ after sintering at $1000{ }^{\circ} \mathrm{C}$, resulting in a decrease in the length and volume of the residues. However, the weight loss of the MVQ composites with the addition of different borates is similar, which is because the weight percents of the inorganic fillers such as the borates and halloysites are almost the same.

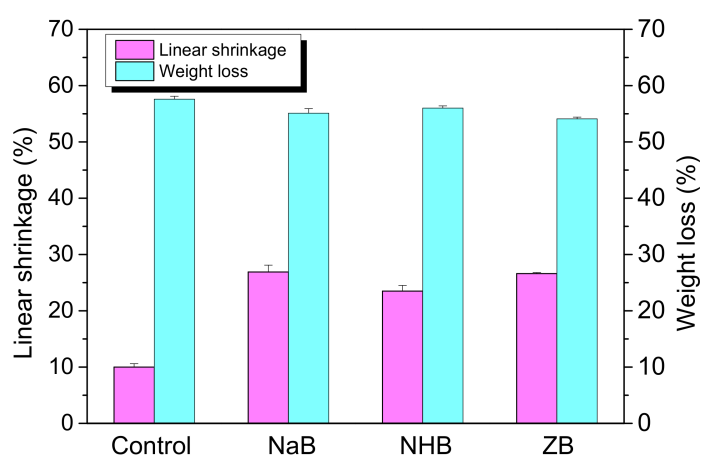

Figure 5. Linear shrinkage and weight loss of the ceramic residues by incorporation of different borates. 


\subsection{Surface Morphology of Ceramizable MVQ/HNT Composites and Corresponding Ceramic Residues}

The surface morphology of the ceramizable MVQ/HNT composites and corresponding ceramic residues with the addition of different borates was shown in Figure 6. It is exhibited that the control sample and ZB composite is relatively smooth, however, the surfaces of the $\mathrm{NaB}$ and $\mathrm{NHB}$ composites are rough and dispersed with some white dots. This is because the poor compatibility of sodium tetraborate decahydrate and ammonium pentaborate with MVQ matrix. The corresponding ceramic residues by incorporation of different borates show great linear shrinkage, compared with the control. Moreover, the length of the residue derived from the NHB composite is a little longer than that of another two residues derived from the $\mathrm{NaB}$ and $\mathrm{ZB}$ composites, respectively. This is because the releasing of ammonia and water stream during the decomposition of ammonium pentaborate leads to an increase in the porosity of ceramic residues and then a decrease in the linear shrinkage. The color of the composites turns from gray (before firing) to pink (after firing), which might be due to some metal oxides such as $\mathrm{Fe}_{2} \mathrm{O}_{3}$ derived from the impurities in HNTs.

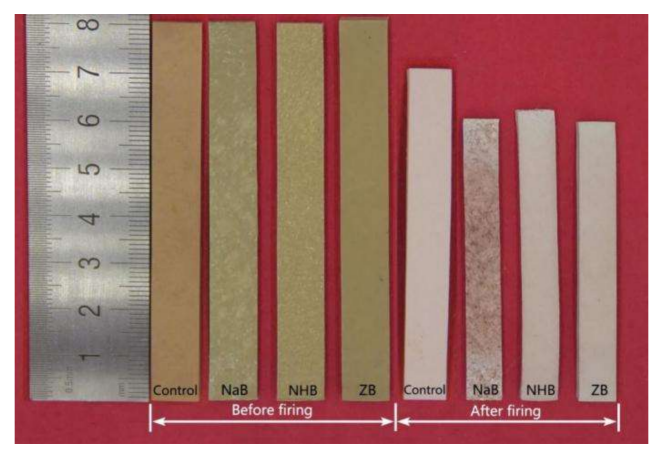

Figure 6. Surface morphology of ceramizable MVQ/HNT composites and corresponding ceramic residues obtained from the pyrolysis products of the composites with the addition of different borates.

\subsection{Effect of the Borates on the Flexural and Impact Strength of Ceramic Residues}

Effect of the borates on the flexural and impact strength of ceramic residues was shown in Figure 7. For the control sample, the flexural and impact strength is $2.9 \mathrm{MPa}$ and $2.1 \mathrm{~J} \cdot \mathrm{m}^{-1}$, respectively. The residues derived from the $\mathrm{ZB}$ composites exhibit the maximum flexural and impact strength with the values of $28.7 \mathrm{MPa}$ and $4.5 \mathrm{~J} \cdot \mathrm{m}^{-1}$, which are $890 \%$ and $114 \%$ higher than those of the control, respectively. This is because the high thermal stability of zinc borate helps to form dense ceramic structure with improved ceramic strength. However, the residues derived from the NHB composites show the minimum flexural and impact strength with the values of $13 \mathrm{MPa}$ and $2.7 \mathrm{~J} \cdot \mathrm{m}^{-1}$ respectively, which is due to the releasing of ammonia and crystal water with the decomposition of ammonium pentaborate, destroying the dense structure of the residues.

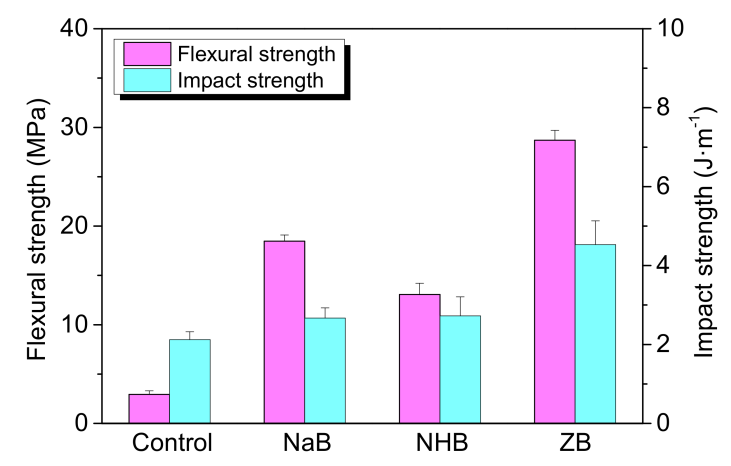

Figure 7. Effect of three borates on the flexural and impact strength of ceramic residues. 


\subsection{SEM Analysis}

The tensile fractures of the control (Figure 8a), ceramizable NaB (Figure 8b), NHB (Figure 8c), and $\mathrm{ZB}$ (Figure $8 \mathrm{~d}$ ) composites and the impact fractures of the ceramic residues derived from the decomposition of the composites were shown in Figure 8. Before sintering, the tensile fractures of all the composites are smooth and dense. However, it is found that there are more holes in the impact fractures of the residues containing the borates than that of the control residue (Figure 8e). However, there are fewer cavities in the impact fracture of the $\mathrm{ZB}$ residue (Figure $8 \mathrm{~h}$ ) than those of $\mathrm{NaB}$ (Figure 8f) and $\mathrm{NHB}$ (Figure $8 \mathrm{~g}$ ) residues, indicating that more $\mathrm{B}_{2} \mathrm{O}_{3}$ (liquid phase) generated by the decomposition of zinc borate makes the ceramic residues denser. The releasing of more crystalliferous water or ammonia accompanied by the decomposition of sodium tetraborate decahydrate and ammonium pentaborate might result in many holes in the fracture surface.
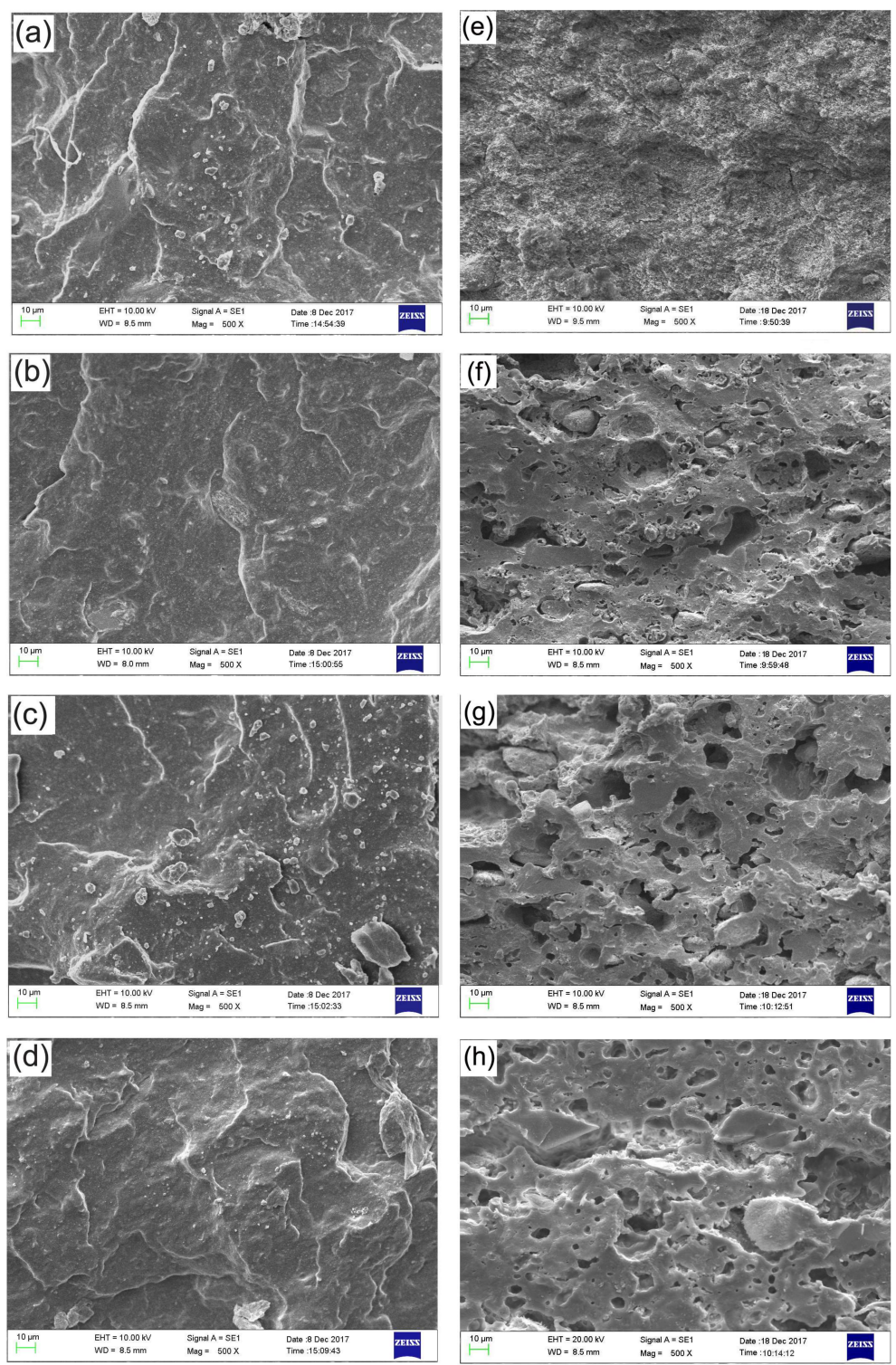

Figure 8. Morphology of tensile fracture surfaces of (a) the control and ceramizable, (b) NaB, (c) NHB, and (d) ZB composites and impact fracture surfaces of (e) the ceramic residue obtained from the control composite and the ceramic ones derived from the decomposition of the (f) NaB, (g) NHB, and (h) ZB composites, respectively. 


\subsection{XRD Analysis}

XRD spectra of the ceramic residues obtained from the decomposition of the NaB, NHB, and ZB composites after sintering at $1000{ }^{\circ} \mathrm{C}$ was shown in Figure 9. The residues without any borates were chosen as control. For the control residue, there is no diffraction peaks in the XRD spectrum, indicating no crystalline phases existed in the residues. For the residues with the addition of the borates, the main crystalline phases $[25,26]$ include quartz $\left(\mathrm{SiO}_{2}\right)(\mathrm{JCPDS}$ no. 46-1045) and cristobalite (JCPDS no. 76-1390), anorthite $\left(\mathrm{CaAl}_{2} \mathrm{Si}_{2} \mathrm{O}_{8}\right)$ (JCPDS no. 41-1486) and mullite $\left(\mathrm{Al}_{6} \mathrm{Si}_{2} \mathrm{O}_{13}\right)$ (JCPDS no. 15-0776). It is known that amorphous silica $\left(\mathrm{SiO}_{2}\right)$ was obtained from pyrolysis of $\mathrm{MVQ}$, and alumina $\left(\mathrm{Al}_{2} \mathrm{O}_{3}\right)$ was obtained from the decomposition of halloysites and calcium oxide $(\mathrm{CaO})$ was obtained from the degradation of calcium carbonate $\left(\mathrm{CaCO}_{3}\right)$ in the sintering process. Because the eutectic reactions were triggered within $\mathrm{SiO}_{2}, \mathrm{Al}_{2} \mathrm{O}_{3}$, and $\mathrm{CaO}$, some new crystals such as cristobalite, quartz, anorthite, and mullite emerged after cooling of the residues. However, for the residue derived from the $\mathrm{ZB}$ composite, the diffraction peaks $\left(2 \theta=31.227^{\circ}, 36.772^{\circ}\right)$ appear in the XRD spectra, indicating the generation of gahnite $\left(\mathrm{ZnAl}_{2} \mathrm{O}_{4}\right)$ (JCPDS no. 05-0669), which is due to the eutectic reaction between $\mathrm{ZnO}$ and $\mathrm{Al}_{2} \mathrm{O}_{3}$.

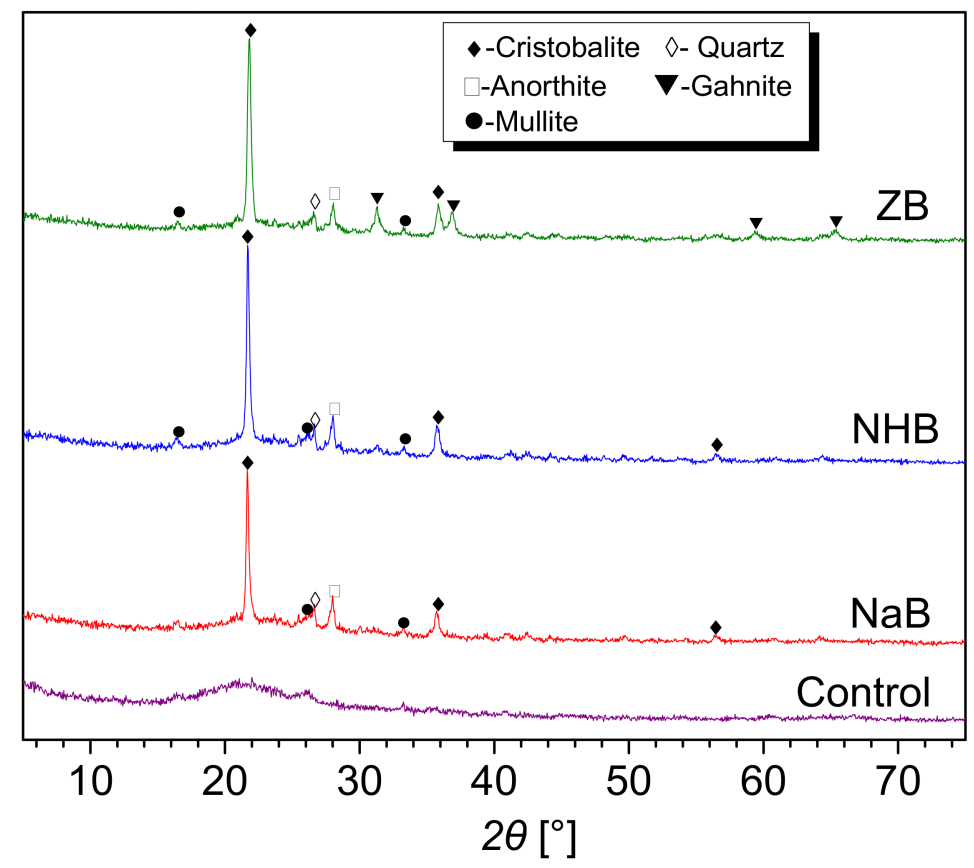

Figure 9. XRD spectra of the ceramic residues obtained from the MVQ/HNT composites with the addition of different borates.

\subsection{Proposed Ceramizable Mechanism}

The decomposition of three berates and proposed eutectic reactions between different metal oxides are shown in Equations (3)-(14). According to the TGA results in Figure 2, sodium tetraborate decahydrate $\left(\mathrm{Na}_{2} \mathrm{~B}_{4} \mathrm{O}_{7} \cdot 10 \mathrm{H}_{2} \mathrm{O}\right)$ is white crystal, which will be decomposed to $\mathrm{B}_{2} \mathrm{O}_{3}$ at elevated temperature. Ammonium pentaborate $\left(\mathrm{NH}_{4} \mathrm{~B}_{5} \mathrm{O}_{8} \cdot 4 \mathrm{H}_{2} \mathrm{O}\right)$, which is decomposed to $\mathrm{B}_{2} \mathrm{O}_{3}$ at the temperature up to $470{ }^{\circ} \mathrm{C}$. Zinc borate $\left(2 \mathrm{ZnO} \cdot 3 \mathrm{~B}_{2} \mathrm{O}_{3} \cdot 3.5 \mathrm{H}_{2} \mathrm{O}\right)$ can act as an inorganic boron-containing flame retardant, which is decomposed to $\mathrm{B}_{2} \mathrm{O}_{3}$ from 370 to $450{ }^{\circ} \mathrm{C}$ [20]. The thermal decomposition of halloysites involves dehydroxylation at $500 \sim 900{ }^{\circ} \mathrm{C}$, the silica and alumina are originally formed in the tetrahedral and octahedral sheets, respectively. Nano sized $(5-40 \mathrm{~nm}) \gamma-\mathrm{Al}_{2} \mathrm{O}_{3}$ is generated at $900 \sim 1000{ }^{\circ} \mathrm{C}$ [27]. There are eutectic reactions between some metal oxides such as $\mathrm{Al}_{2} \mathrm{O}_{3}, \mathrm{SiO}_{2}$, $\mathrm{CaO}$, and $\mathrm{ZnO}$ to generate anorthite $\left(\mathrm{CaAl}_{2} \mathrm{Si}_{2} \mathrm{O}_{8}\right)$, mullite $\left(\mathrm{Al}_{6} \mathrm{Si}_{2} \mathrm{O}_{13}\right)$, gahnite $\left(\mathrm{ZnAl}_{2} \mathrm{O}_{4}\right)$, etc. All the crystals will strengthen the ceramic residues and increase their flexural and impact strength [28]. 
Decomposition of sodium tetraborate decahydrate:

$$
\begin{gathered}
70 \sim 100{ }^{\circ} \mathrm{C} \mathrm{Na}_{2} \mathrm{~B}_{4} \mathrm{O}_{7} \cdot 10 \mathrm{H}_{2} \mathrm{O} \rightarrow \mathrm{Na}_{2} \mathrm{~B}_{4} \mathrm{O}_{7}+10 \mathrm{H}_{2} \mathrm{O} \uparrow \\
100 \sim 500{ }^{\circ} \mathrm{C} \mathrm{Na}_{2} \mathrm{~B}_{4} \mathrm{O}_{7} \rightarrow 2 \mathrm{NaBO}_{2}+\mathrm{B}_{2} \mathrm{O}_{3}
\end{gathered}
$$

Decomposition of ammonium pentaborate:

$$
\begin{aligned}
& 100 \sim 200{ }^{\circ} \mathrm{C} \mathrm{NH}_{4} \mathrm{~B}_{5} \mathrm{O}_{8} \cdot 4 \mathrm{H}_{2} \mathrm{O} \rightarrow \mathrm{NH}_{4} \mathrm{~B}_{5} \mathrm{O}_{8} \cdot \mathrm{H}_{2} \mathrm{O}+3 \mathrm{H}_{2} \mathrm{O} \uparrow \\
& 200 \sim 350{ }^{\circ} \mathrm{C} \mathrm{NH}_{4} \mathrm{~B}_{5} \mathrm{O}_{8} \cdot \mathrm{H}_{2} \mathrm{O} \rightarrow \mathrm{HB}_{5} \mathrm{O}_{8}+\mathrm{H}_{2} \mathrm{O} \uparrow+\mathrm{NH}_{3} \uparrow \\
& 350 \sim 470{ }^{\circ} \mathrm{C} 2 \mathrm{HB}_{5} \mathrm{O}_{8} \rightarrow 5 \mathrm{~B}_{2} \mathrm{O}_{3}+\mathrm{H}_{2} \mathrm{O} \uparrow
\end{aligned}
$$

Decomposition of zinc borate:

$$
370 \sim 500{ }^{\circ} \mathrm{C} 2 \mathrm{ZnO} \cdot 3 \mathrm{~B}_{2} \mathrm{O}_{3} \cdot 3.5 \mathrm{H}_{2} \mathrm{O} \rightarrow 2 \mathrm{ZnO}+3 \mathrm{~B}_{2} \mathrm{O}_{3}+3.5 \mathrm{H}_{2} \mathrm{O} \uparrow
$$

Transformation of silica:

$$
1000{ }^{\circ} \mathrm{C} \mathrm{SiO}_{2} \text { (amorphous) } \rightarrow \mathrm{SiO}_{2} \text { (crystal) }
$$

Decomposition of halloysites:

$$
\begin{gathered}
500 \sim 900^{\circ} \mathrm{C} \mathrm{Al}_{2}(\mathrm{OH})_{4} \mathrm{Si}_{2} \mathrm{O}_{5} \cdot 2 \mathrm{H}_{2} \mathrm{O} \text { (Halloysites) } \rightarrow \mathrm{Al}_{2} \mathrm{O}_{3} \cdot 2 \mathrm{SiO}_{2}+4 \mathrm{H}_{2} \mathrm{O} \uparrow \\
900 \sim 1000^{\circ} \mathrm{C} \mathrm{Al}_{2} \mathrm{O}_{3} \cdot 2 \mathrm{SiO}_{2} \rightarrow \mathrm{Al}_{2} \mathrm{O}_{3}+2 \mathrm{SiO}_{2}
\end{gathered}
$$

Proposed eutectic reactions:

$$
\begin{aligned}
2 \mathrm{SiO}_{2}+3 \mathrm{Al}_{2} \mathrm{O}_{3} & \rightarrow \mathrm{Al}_{6} \mathrm{Si}_{2} \mathrm{O}_{13} \text { (mullite) } \\
\mathrm{CaO}+2 \mathrm{SiO}_{2}+\mathrm{Al}_{2} \mathrm{O}_{3} & \rightarrow \mathrm{CaAl}_{2} \mathrm{Si}_{2} \mathrm{O}_{8} \text { (anorthite) } \\
\mathrm{ZnO}+\mathrm{Al}_{2} \mathrm{O}_{3} & \rightarrow \mathrm{ZnAl}_{2} \mathrm{O}_{4} \text { (gahnite) }
\end{aligned}
$$

\section{Conclusions}

The mechanical and electrical properties of ceramizable silicone rubber (MVQ)-based composites with the addition of zinc borate are better than those of sodium tetraborate decahydrate and ammonium pentaborate. The tensile strength of MVQ/HNT composites with zinc borate is $69 \%$ and $42 \%$ bigger than that with sodium tetraborate decahydrate and ammonium pentaborate, respectively. The volume and surface resistivity of MVQ/HNT composites with zinc borate are higher than those with sodium tetraborate decahydrate and ammonium pentaborate, showing the values of $1.7 \times 10^{14} \Omega \cdot \mathrm{m}$ and $7.9 \times 10^{14} \Omega$, respectively. The flexural and impact strength of the ceramic residues derived from decomposition of the composites by incorporation of zinc borate are $28.7 \mathrm{MPa}$ and $4.5 \mathrm{~J} \cdot \mathrm{m}^{-1}$ respectively due to the dense structure in the residues. Furthermore, the eutectic reactions between zinc borate and halloysite will generate some crystals such as mullite and gahnite in the residues after sintering at $1000{ }^{\circ} \mathrm{C}$, which further increases the flexural and impact strength of the residues.

Acknowledgments: This work was supported by the National Natural Science Foundation of China (grant no. 51103048), and Science and Technology Development Project of Zhongshan City (no. 2016F2FC0014), and Science and Technology Planning Project of Guangdong Province, China (no. 2016A010103001).

Author Contributions: Jianhua Guo conceived and designed the study and wrote the paper. Xuming Chen and Yong Zhang performed the experiments. All authors read and approved the manuscript.

Conflicts of Interest: The authors declare no conflict of interest. 


\section{References}

1. Hayashida, K.; Tsuge, S.; Ohtani, H. Flame retardant mechanism of polydimethylsiloxane material containing platinum compound studied by analytical pyrolysis techniques and alkaline hydrolysis gas chromatography. Polymer 2003, 44, 5611-5616. [CrossRef]

2. Hanu, L.G.; Simon, G.P.; Cheng, Y.B. Preferential orientation of muscovite in ceramizable silicone composites. Mater. Sci. Eng. A 2005, 398, 180-187. [CrossRef]

3. Mansouri, J.; Burford, R.P.; Cheng, Y.B.; Hanu, L. Formation of strong ceramified ash from silicone-based compositions. J. Mater. Sci. 2005, 40, 5741-5749. [CrossRef]

4. Gong, X.H.; Wu, T.Y.; Ma, J.; Zhao, D.; Shen, Y.C.; Wang, T.W. Improved self-supporting property of ceramifying silicone rubber composites by forming crystalline phase at high temperatures. J. Alloys Compd. 2017, 706, 322-329. [CrossRef]

5. Yu, L.; Zhou, S.; Zou, H.; Liang, M. Thermal stability and ablation properties study of aluminum silicate ceramic fiber and acicular wollastonite filled silicone rubber composite. J. Appl. Polym. Sci. 2014, 131, 1-15. [CrossRef]

6. Lou, F.P.; Yan, W.; Guo, W.H.; Wei, T.; Li, Q.Y. Preparation and properties of ceramifiable flame-retarded silicone rubber composites. J. Therm. Anal. Calorim. 2017, 130, 813-821. [CrossRef]

7. Anyszka, R.; Bieliński, D.M.; Pędzich, Z.; Szumera, M. Influence of surface-modified montmorillonites on properties of silicone rubber-based ceramizable composites. J. Therm. Anal. Calorim. 2015, 119, 111-121. [CrossRef]

8. Guo, J.H.; Zhang, Y.; Li, H.J.; Zhang, X. Effect of the sintering temperature on the microstructure, properties and formation mechanism of ceramic materials obtained from polysiloxane elastomer-based ceramizable composites. J. Alloys Compd. 2016, 678, 499-505. [CrossRef]

9. Lou, F.P.; Cheng, L.H.; Li, Q.Y.; Wei, T.; Guan, X.Y.; Guo, W.H. The combination of glass dust and glass fiber as fluxing agents for ceramizable silicone rubber composites. RSC Adv. 2017, 7, 38805-38811. [CrossRef]

10. Hu, S.; Chen, F.; Li, J.G.; Shen, Q.; Huang, Z.X.; Zhang, M.L. The ceramifying process and mechanical properties of silicone rubber/ammonium polyphosphate/aluminium hydroxide/mica composites. Polym. Degrad. Stabil. 2016, 126, 196-203. [CrossRef]

11. Hamdani, S.; Pommier, A.; Longuet, C.; Lopez-Cuesta, J.M.; Ganachaud, F. Calcium and aluminium-based fillers as flame-retardant additives in silicone matrices II. Analyses on composite residues from an industrial-based pyrolysis test. Polym. Degrad. Stabil. 2011, 96, 1562-1572. [CrossRef]

12. Imiela, M.; Anyszka, R.; Bieliński, D.M.; Pędzich, Z.; Napierała, M.Z.; Szumera, M. Effect of carbon fibers on thermal properties and mechanical strength of ceramizable composites based on silicone rubber. J. Therm. Anal. Calorim. 2016, 124, 197-203. [CrossRef]

13. Marosi, G.; Márton, A.; Anna, P.; Bertalan, G.; Marosföi, B.; Szép, A. Ceramic precursor in flame retardant systems. Polym. Degrad. Stabil. 2002, 77, 259-265. [CrossRef]

14. Mansouri, J.; Wood, C.; Roberts, K.; Cheng, Y.B.; Burford, R.P. Investigation of the ceramifying process of modified silicone-silicate compositions. J. Mater. Sci. 2007, 42, 6046-6055. [CrossRef]

15. Guo, J.H.; Gao, W.; Wang, Y.; Liang, D.; Li, H.J.; Zhang, X. Effect of glass frit with low softening temperature on the properties, microstructure and formation mechanism of polysiloxane elastomer-based ceramizable composites. Polym. Degrad. Stabil. 2017, 136, 71-79. [CrossRef]

16. Hanu, L.G.; Simon, G.P.; Cheng, Y.B. Thermal stability and flammability of silicone polymer composites. Polym. Degrad. Stabil. 2006, 91, 1373-1379. [CrossRef]

17. Shen, K.K.; Kochesfahani, S.; Jouffret, F. Zinc borates as multifunctional polymer additives. Polym. Adv. Technol. 2010, 19, 469-474. [CrossRef]

18. Al-Hassany, Z.; Genovese, A.; Shanks, R.A. Fire-retardant and fire-barrier poly(vinyl acetate) composites for sealant application. Express Polym. Lett. 2010, 4, 79-93. [CrossRef]

19. Anyszka, R.; Bielinski, D.M.; Jędrzejczyk, M. Thermal behavior of silicone rubber based ceramizable composites characterized by fourier transform infrared (FT-IR) spectroscopy and microcalorimetry. Appl. Spectrosc. 2013, 67, 1437-1440. [CrossRef] [PubMed]

20. Anyszka, R.; Bieliński, D.M.; Pędzich, Z.; Dul, J. Ceramizable silicone rubber-based composites. Adv. Sci. Technol. 2012, 66, 82-88.

21. Wilson, I.R. Kaolin and halloysite deposits of China. Clay Miner. 2004, 39, 1-15. [CrossRef] 
22. Lvov, Y.M.; Shchukin, D.G.; Möhwald, H.; Price, R.R. Halloysite clay nanotubes for controlled release of protective agents. ACS Nano 2008, 2, 814-820. [CrossRef] [PubMed]

23. Pasbakhsh, P.; Ismail, H.; Fauzi, M.N.A.; Bakar, A.A. EPDM/modified halloysite nanocomposites. Appl. Clay Sci. 2010, 48, 405-413. [CrossRef]

24. Alwaan, I.M.; Hassan, A.; Piah, M.A.M. Effect of zinc borate on mechanical and dielectric properties of metallocene linear low-density polyethylene/rubbers/magnesium oxide composite for wire and cable applications. Iran Polym. J. 2015, 24, 279-288. [CrossRef]

25. Yang, S.N.; Lv, G.P.; Liu, Y.; Wang, Q. Synergism of polysiloxane and zinc borate flame retardant polycarbonate. Polym. Degrad. Stabil. 2013, 98, 2795-2800. [CrossRef]

26. Wang, J.; Ji, C.; Yan, Y.; Zhao, D.; Shi, L. Mechanical and ceramizable properties of silicone rubber filled with different inorganic fillers. Polym. Degrad. Stabil. 2015, 121, 149-156. [CrossRef]

27. Yuan, P.; Tan, D.Y.; Annabi-Bergaya, F.; Yan, W.C.; Fan, M.D.; Liu, D.; He, H.P. Changes in structure, morphology, porosity, and surface activity of mesoporous halloysite nanotubes under heating. Clays Clay Miner. 2012, 60, 561-573. [CrossRef]

28. Kokubo, T.; Ito, S.; Sakka, S.; Yamamuro, T. Formation of a high-strength bioactive glass-ceramic in the system MgO-CaO-SiO $2-\mathrm{P}_{2} \mathrm{O}_{5}$. J. Mater. Sci. 1986, 21, 536-540. [CrossRef]

(C) 2018 by the authors. Licensee MDPI, Basel, Switzerland. This article is an open access article distributed under the terms and conditions of the Creative Commons Attribution (CC BY) license (http:/ / creativecommons.org/licenses/by/4.0/). 